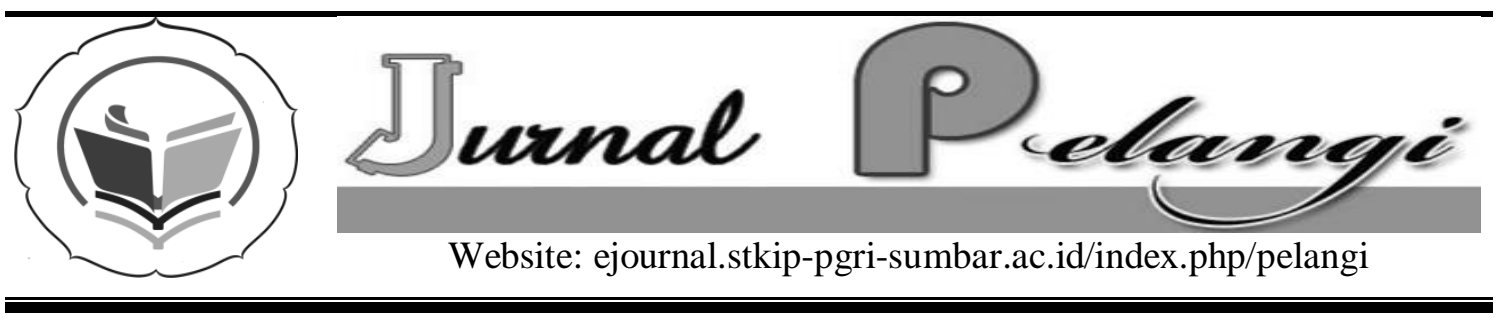

\title{
PENINGKATKAN HASIL BELAJAR MATEMATIKA SISWA SD KELAS V MELALUI MODEL PEMBELAJARAN KOOPERATIF TIPE STAD
}

\author{
Mufarizuddin \\ Universitas Pahlawan Tuanku Tambusai \\ Zuddin.unimed@gmail.com
}

INFO ARTIKEL

Diterima:

23 Mei 2017

Direview:

9 Juni 2017

Disetujui:

31 Agustus 2017

\section{Kata Kunci:}

Hasil belajar matematika, pembelajaran kooperatif, STAD

\begin{abstract}
Abstrak
Penelitian ini bertujuan untuk mengetahui peningkatan hasil belajar siswa SD kelas $V$ melalui penerapan model pembelajaran kooperatif tipe STAD. Penelitian ini merupakan penelitian tindakan kelas. Subjek Penelitian ini adalah siswa kelas VA Sekolah Dasar Negeri 016 Bangkinang yang berjumlah 32 orang siswa. Berdasarkan hasil penelitian, dapat diketahui bahwa ada peningkatan hasil belajar sebelum dilakukan tindakan ke siklus I dan ke siklus II. Sebelum dilakukan tindakan, hasil belajar siswa diperoleh 46.9\%, terjadi peningkatan pada siklus I dengan persentase $68.8 \%$ dengan jumlah siswa yang tuntas sebanyak 22 orang siswa. Hasil belajar siswa pada siklus II mengalami peningkatan menjadi $90.6 \%$ dengan jumlah siswa tuntas sebanyak 29 orang siswa. Hal ini membuktikan bahwa penerapan model pembelajaran kooperatif tipe STAD dapat meningkatkan hasil belajar siswa.
\end{abstract}

Abstract
This study aims to determine the increase in student learning
outcomes of grade V through the application of STAD model.
This research is a classroom action research. The subject of
this research is the students of VA class of Public Elementary
School 016 Bangkinang which amounted to 32 students. Based
on the research results, it can be seen that there is an increase
in learning outcomes before the action is taken to cycle I and
to cycle II. Before the action, students' learning outcomes
obtained $46.9 \%$ an increase in cycle I with percentage of
$68.8 \%$ with a total number of students who completed 22
students. Students' learning outcomes in cycle II has increased
to $90.6 \%$ with the total number of students complete as many
as 29 students. This proves that the application of STAD model
can improve student learning outcomes.




\section{PENDAHULUAN}

Pendidikan sekolah dasar sangat penting untuk membangun dasar pendidikan yang kuat. Pembelajaran di sekolah dasar akan mengembangkan pola pikir dan kreativitas siswa. Heruman (2007:19), menyatakan bahwa siswa sekolah dasar umumnya berkisar antara 6 atau 7 tahun, sampai 12 atau 13 tahun. Kemampuan yang tampak pada fase ini adalah kemampuan dalam proses berpikir untuk mengoperasikan kaidahkaidah logika, meskipun masih terikat dengan objek yang bersifat kongkret. Mata pelajaran Matematika juga mulai diajarkan di tingkat Sekolah Dasar (SD).

Matematika adalah studi besaran, struktur, ruang, relasi, perubahan dan beraneka topik poladan bentuk. Dalam batasan pengertian pembelajaran yang dilakukan di sekolah,pembelajaran Matematika dimaksudkan sebagai proses yang sengaja dirancang dengan tujuan untuk menciptakan suasana lingkungan kelas atau sekolah yang memungkinkan kegiatan siswa belajar Matematika di sekolah. Dari pengertian tersebut jelas kiranya bahwa unsur pokok dalam pembelajaran Matematika SD adalah guru sebagai salah satu perancang proses, proses yang sengaja dirancang selanjutnya disebut proses pembelajaran, siswa sebagai pelaksana kegiatan belajar, dan Matematika sebagai objek yang dipelajari di salah satu bidang studi dalam pelajaran.

Depdiknas (2006:16), memaparkan bahwa tujuan pembelajaran Matematika adalah agar peserta didik memiliki kemampuan sebagai berikut:

1. Memahami konsep Matematika, menjelaskan keterkaitan antar konsep dan mengaplikasikan konsep secara jelas, akurat dan tepat dalam pemecahan masalah.
2. Menggunakan penalaran pada pola dan sifat, melakukan manipulasi Matematika dalam membuat generalisasi, menyusun buku atau menjelaskan gagasan dan pernyataan Matematika.

3. Memecahkan masalah yang meliputi kemampuan memahami masalah, merancang model Matematika, menyelesaikan model dan menafsirkan solusi yang diperoleh.

4. Mengkomunikasikan gagasan dengan simbol, tabel, diagram, atau media lain untuk memperjelas keadaan atau masalah.

5. Memiliki sikap menghargai kegunaan Matematika dalam kehidupan, yaitu memiliki rasa ingin tahu, perhatian dan minat dalam mempelajari Matematika serta sikap ulet dan percaya diri dalam pemecahan masalah.

Mengingat pentingnya penguasaan Matematika di sekolah, guru harus pandai membaca situasi kelas agar suasana belajar dapat terlaksana dengan baik.Apabila suasana mendukung, maka materi yang diberikan dapat dipahami dengan baik. Hal ini diharapkan akanmampu meningkatkan prestasi belajar siswa dan pencapaian KKM yang telah ditetapkan sekolah.

Berdasarkan pengamatan proses pembelajaran di kelas dewasa ini, kurang meningkatkan aktifitas siswa, terutama dalam pelajaran Matematika. Masih banyak dijumpai guru yang menggunakan metode konvensional secara monoton dalam kegiatan pembelajaran di kelas, sehingga suasana pembelajaran terkesan kaku dan didominasi oleh guru. Hal ini dapat dilihat dari penyampaian materi oleh guru dengan metode ceramah, siswa tenang, mendengarkan, dan mencatat apa yang disampaikan guru. Oleh sebab itu, 
sedikit peluang bagi siswa untuk bertanya.Minimnya media pembelajaran, seperti buku paket yang dipakai guru hanya terfokus pada satu buku saja. Dalam proses pembelajaran terkadang perhatian guru lebih dominan kepada siswa yang pandai, sedangkan siswa yang lain diabaikan.

Keberhasilan kegiatan belajar mengajar sangat ditentukan oleh berbagai faktor yang berkaitan dengan proses belajar mengajar. Salah satu faktor yang sangat mendukung keberhasilan guru dalam proses belajar mengajar yaitu kemampuan guru dalam menguasai dan menerapkan metode pembelajaran dengan mengacu pada karakteristik materi, kondisi fisik dan psikis siswa serta tingkat kecerdasannya. Hal ini sangat relevan dengan tugas seorang guru dalam mengenali perbedaan karakter siswanya.

Keberhasilan siswa dalam penguasaan materi mata pelajaran Matematika dapat dilihat dari hasil belajar Matematika. Siswa dikatakan berhasil jika hasil belajar Matematikanya mencapai Kriteria Ketuntasan Minimum (KKM) yang telah ditetapkan oleh setiap sekolah.Sebaliknya jika siswa tersebut mendapat nilai dibawah nilai standar ketuntasan yang telah ditetapkan, maka siswa tersebut belum dapat dikatakan berhasil dalam belajar Matematika. Berdasarkan hasil tes pada siswa kelas $\mathrm{V}$ SD Negeri 016 Bangkinang dapat dilihat pada Tabel 1.

Berdasarkan data Tabel 1 dapat dilihat bahwa materi bilangan bulat anak yang mencapai KKM sebesar $75 \%$. Pada meteri pengukuran anak yang dinyatakan tuntas sudah mencapaI 65\% sedangakan untuk materi Bangun Ruang anak yang belum mencapai KKM masih sangat rendah yaitu sebesar 53\% atau masih lebih separuh dari jumlah anak yang ada dalam satu kelas yaitu 32 orang.Hasil belajar Matematika siswa kelas V SDN 016 Bangkinang pada materi pokok Bangun Ruang masih rendah. Jumlah siswa yang mencapai Kriteria Ketuntasan Minimum (KKM) yang ditetapkan sekolah yaitu 65 , hanya 46,87 $\%$ yaitu: 15 orang siswa dari 32 orang siswa, sedangkan siswa yang tidak mencapai KKM yaitu: 53,12 \% sebanding dengan 17 orang siswa dari 32 orang siswa.

Keberhasilan pencapaian hasil belajar tidak terlepas dari model pembelajaran yang ditetapkan oleh guru di kelas. Model pembelajaran dilaksanakan untuk menciptakan suasana belajar yang membuat siswa mudah menerima pelajaran. Penggunaan metode ceramah banyak digunakan oleh para guru dalam proses pembelajaran, sehingga siswa jenuh dan bosan dalam belajar.

Suasana kelas perlu direncanakan dan dibangun sedemikian rupa sehingga siswa mendapatkan kesempatan untuk berinteraksi satu sama lain. Dalam interaksi ini, siswa akan membentuk komunitas yang memungkinkan mereka untuk menyenangi pelajaran. Oleh karena itu, pengajar perlu menciptakan suasana belajar sedemikian rupa sehingga siswa bekerja sama secara gotong royong.

Sangat banyak penelitian dilakukan terpisah oleh orang yang berbeda dalam konteks yang berlainan mengenai metode pembelajaran cooperative learning.Data tersebut menunjukkan bahwa suasana belajar cooperative learning menghasilkan prestasi yang lebih tinggi, hubungan yang lebih positif, dan penyesuaian psikologis yang lebih baik daripada suasana belajar yang penuh dengan persaingan dan memisahmisahkan siswa. 
Tabel 1. Hasil Belajar Matematika Siswa Kelas V SDN 016 Bangkinang T.P. 2016/2017

\begin{tabular}{cccccc}
\hline Materi & $\begin{array}{c}\text { Jumlah } \\
\text { Siswa } \\
\text { Kelas V }\end{array}$ & $\begin{array}{c}\text { Jumlah } \\
\text { Siswa } \\
\text { Tuntas }\end{array}$ & Persentase & $\begin{array}{c}\text { Jumlah } \\
\text { Siswa tidak } \\
\text { Tuntas }\end{array}$ & Persentase \\
\hline Bilangan bulat & 32 & 24 & $75 \%$ & 8 & $25 \%$ \\
\hline Pengukuran & 32 & 21 & $65,62 \%$ & 11 & $34,37 \%$ \\
\hline Bangun Ruang & 32 & 15 & $46,87 \%$ & 17 & $53,12 \%$ \\
\hline
\end{tabular}

Sumber: SDN 147 Pekanbaru

Pembelajaran kooperatif membuat siswa merasa dibutuhkan dalam proses pembelajaran, karena merasa dipentingkan dalam pembelajaran maka siswa merasa tertantang. Dengan tantangan yang ada maka rasa tangung jawab akan tumbuh untuk membuat kelompoknya mendapatkan pujian dari teman dan guru. Hanya dengan penguasaan materi dan aktif dalam proses pembelajaran yang dapat mewujudkan keinginan kelompoknya. Bila setiap siswa mempunyai rasa tanggung jawab terhadap kelompoknya, maka suasana belajar akan lebih menantang siswa untuk lebih aktif dan suasana belajar yang diharapkan dapat tercapai. Oleh karena itu, untuk membuat suasana belajar yang menantang dan lebih aktif maka peneliti ingin melakukan Penelitian Tindakan Kelas (PTK) dengan menggunakan model Kooperatf Tipe STAD dengan harapan agar hasil belajar anak bisa mencapai KKM yang sudah ditetapkan.

Berdasarkan uraian di atas, tujuan penelitian ini adalah untuk mengetahui peningkatan hasil belajar siswa SD kelas $\mathrm{V}$ melalui penerapan model pembelajaran kooperatif tipe STAD.

\section{METODE PENELITIAN}

Aktivitas Guru dan siswa dapat diketahui dengan menggunakan rumus :

$$
P=\frac{F}{N} \times 100 \%
$$

Keterangan :

$\mathrm{P}=$ angka persentase

$\mathrm{F}=$ frekuensi aktivitas guru

$\mathrm{N}=$ total aktivitas guru

Dengan menggunakan kriteria sebagai berikut:

Tabel 2. Kriteria Aktivitas Guru

\begin{tabular}{ccc}
\hline No & Interval & Kategari \\
\hline 1. & $91-100$ & Baik sekali \\
2. & $71-90$ & Baik \\
3. & $61-70$ & Cukup \\
4. & $<60$ & Kurang \\
\hline
\end{tabular}

Sumber : Sudijono, 1995

Hasil belajar siswa dapat dihitung dengan menggunakan rumus

$$
\text { Skor }=\frac{\text { Skoryangdiperoleh }}{\text { SkorMaksimal }} \times 100
$$

(KTSP, 2007:369)

Dalam penelitian ini siswa dikatakan berhasil apabila hasil yang didapatkan telah mencapai Kriteria Ketuntasan Minimum (KKM) yang telah ditentukan oleh sekolah yaitu adalah 65 untuk pelajaran Matematika. Ketuntasan dapat diketahui dengan menggunakan rumus :

$\mathrm{KB}=\frac{T}{T t} x 100 ; \quad$ (Trianto, 2009:241)

Dimana :

$\mathrm{KB}=$ ketuntasan belajar

$\mathrm{T}=$ jumlah skor yang diperoleh siswa

$\mathrm{Tt}=$ jumlah skor total 
Dalam penelitian ini siswa dikatakan tuntas jika telah mencapai Kriteria Ketuntasan Minimum (KKM) yang telah ditentukan oleh sekolah yaitu KKM Matematika adalah 65. Ketuntasan dapat diketahui dengan menggunakan rumus:

$$
\mathrm{KK}=\frac{\text { Jumlahsiswayangtuntas }}{\text { jumlahseluruhsiswa }} \times 100 \%
$$

(Depdikbud dalam Trianto, 2009: 241)

Jika ketuntasan klasikal siswa telah mencapai $85 \%$ dari seluruh siswa, maka hasil belajar siswa secara klasikal telah tercapai dengan baik.

\section{HASIL DAN PEMBAHASAN}

\section{Aktivitas Guru}

Aktivitas guru dalam pembelajaran selama siklus I mulai berlangsung cukup baik, walaupun ada beberapa kelemahan diantaranya guru kesulitan dalam membiasakan untuk menyampaikan tujuan pembelajaran, bingung dalam memotivasi siswa karena sulit untuk mengaitkan dengan kehidupan seharihari, penggunaan waktu kurang sesuai dengan perencanaan, kurang tegas dalam menegur siswa yang melihat hasil kerja temannya. Kesulitan dalam membimbing siswa secara keseluruhan. Tetapi pada siklus II aktivitas guru semakin baik karena guru sudah terbiasa dalam menyampaikan tujuan pembelajaran, dan lebih bersemangat mencari bahan yang berhubungan dengan cara memotivasi siswa yang berkaitan dengan kehidupan sehari-hari serta sudah dapat mengatur waktu dengan baik sesuai dengan yang direncanakan. Guru semakin tegas dalam menegur siswa agar siswa lebih percaya dengan kemampuan sendiri. Guru juga lebih merata dalam membimbing siswa dalam mengerjakan LKS. Hal ini dapat dilihat dari analisis lembar pengamatan penerapan pembelajaran kooperatif tipe STAD aktivitas guru pada siklus I dan II, pada Tabel 3.

Berdasarkan Tabel 3, terlihat perbandingan aktivitas guru pada tiap pertemuan siklus I dan II yang secara umum terjadi peningkatan pada pokok bahasan volume bangun ruang. Dapat dilihat bahwa rata-rata aktivitas guru yang terendah adalah pada aktivitas guru membimbing kelompok untuk bekerja dan belajar.

Tabel 3. Aktivitas Guru pada Siklus I dan II pada Pembelajaran Kooperatif tipe STAD

\begin{tabular}{|l|l|c|c|c|c|}
\hline \multirow{2}{*}{$N_{0}$} & \multicolumn{1}{|c|}{ Aktivitas } & \multicolumn{2}{c|}{ Siklus I } & \multicolumn{2}{c|}{ Siklus II } \\
\cline { 2 - 6 } & Pertemuan I & Pertemuan II & Pertmuan I & Pertemuan II \\
\hline 1 & Guru menyampaikan tujuan dan motivasi siswa & 3 & 3 & 4 & 4 \\
\hline 1 & Guru menyajikan informasi & 3 & 3 & 4 & 4 \\
\hline 2 & $\begin{array}{l}\text { Guru mengorganisasikan siswa ke dalam kelompok-kelompok } \\
\text { belajar }\end{array}$ & 3 & 3 & 4 & 4 \\
\hline 3 & Guru membimbing kelompok bekerja dan belajar & 2 & 2 & 3 & 3 \\
\hline 4 & Guru mengevaluasi hasil belajar siswa & 2 & 3 & 3 & 4 \\
\hline 5 & $\begin{array}{l}\text { Guru memberi penghargaan kepada siswa yang mendapat nilai } \\
\text { terbaik }\end{array}$ & 2 & 3 & 3 & 4 \\
\hline Skor & 15 & 17 & 21 & 23 \\
\hline Rata-rata skor aktivitas guru & 62,5 & 70,8 & 87,5 & 95,8 \\
\hline Kriteria & Sedang & Baik & Baik & Sangat Baik \\
\hline
\end{tabular}


Pertemuan yang memiliki rata-rata terendah adalah pada pertemuan pertama siklus I, hal ini terjadi akibat guru masih belum terbiasa dengan penggunaan pembelajaran kooperatif tipe STAD. Untuk rata-rata tertinggi pada pertemuan ketiga siklus II, hal ini karena guru telah memperbaiki kesalahan yang terjadi pada pertemuan-pertemuan sebelumnya. Peningkatan aktivitas guru dapat dilihat pada grafik Gambar 1.
Dari Tabel 4 dapat dilihat bahwa aktivitas yang dilakukan siswa yang memiliki rata-rata dan persentase terendah adalah pada pertemuan pertama siklus I yaitu sebesar 15.5 atau $48.4 \%$ dan aktivitas siswa yang memiliki ratarata dan persentase tertinggi yaitu pada pertemuan kedua siklus II sebesar 28.5 dan $89.1 \%$. Peningkatan aktivitas siswa dapat dilihat pada Gambar 2.

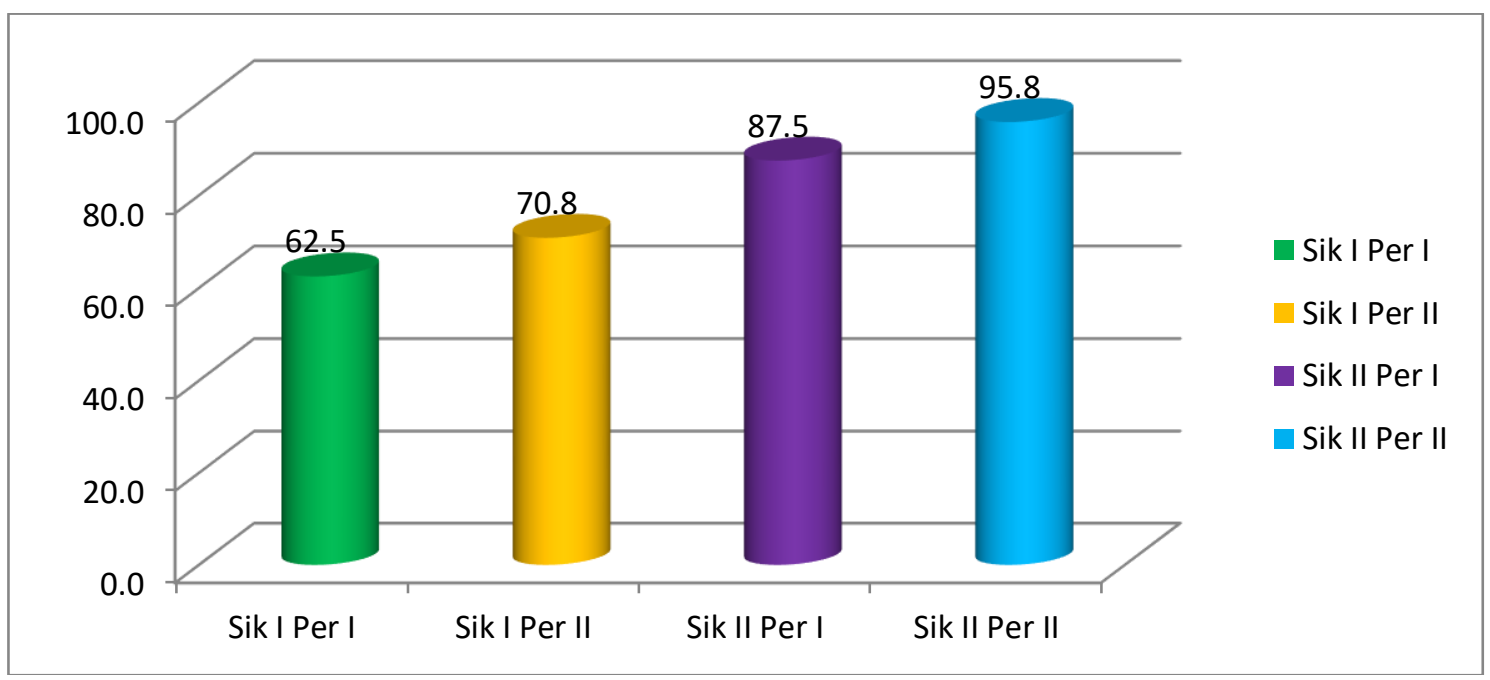

Gambar 1. Peningkatan Aktivitas Guru

Tabel 4. Aktivitas Siswa pada Siklus I dan II pada Pembelajaran Kooperatif tipe STAD

\begin{tabular}{|c|c|c|c|c|c|c|c|c|c|}
\hline \multirow{3}{*}{ No } & \multirow{3}{*}{ Aktivitas } & \multicolumn{4}{|c|}{ Siklus I } & \multicolumn{4}{|c|}{ Siklus I } \\
\hline & & \multicolumn{2}{|c|}{ Pertemuan I } & \multicolumn{2}{|c|}{ Pertemuan II } & \multicolumn{2}{|c|}{ Pertemuan I } & \multicolumn{2}{|c|}{ Pertemuan II } \\
\hline & & Skor & $\%$ & Skor & $\%$ & Skor & $\%$ & Skor & $\%$ \\
\hline 1 & $\begin{array}{l}\text { Siswa membuka pembelajaran dengan memberi } \\
\text { penghormatan pada guru }\end{array}$ & 16 & 50.0 & 21 & 65.6 & 26 & 81.3 & 30 & 93.8 \\
\hline 2 & Siswa mendengarkan intruksi guru dengan baik & 13 & 40.6 & 22 & 68.8 & 25 & 78.1 & 29 & 90.6 \\
\hline 3 & $\begin{array}{l}\text { Siswa membentuk kelompok sesuai dengan intruksi } \\
\text { guru }\end{array}$ & 14 & 43.8 & 21 & 65.6 & 22 & 68.8 & 27 & 84.4 \\
\hline 4 & $\begin{array}{l}\text { Siswa saling bekerjasama dalam menyelesaikan } \\
\text { tugas yang diberikan guru }\end{array}$ & 17 & 53.1 & 19 & 59.4 & 26 & 81.3 & 29 & 90.6 \\
\hline 5 & $\begin{array}{l}\text { Siswa tetap tertib selama proses pembelajaran } \\
\text { berlangsung }\end{array}$ & 16 & 50.0 & 19 & 59.4 & 21 & 65.6 & 27 & 84.4 \\
\hline 6 & $\begin{array}{l}\text { Siswa memperhatikan kesimpulan pembelajaran } \\
\text { yang disampaikan guru }\end{array}$ & 17 & 53.1 & 23 & 71.9 & 24 & 75.0 & 29 & 90.6 \\
\hline & Jumlah & 93.0 & 290.6 & 125.0 & 390.6 & 144.0 & 450.0 & 171.0 & 534.4 \\
\hline & Rata-rata & 15.5 & 48.4 & 20.8 & 65.1 & 24.0 & 75.0 & 28.5 & 89.1 \\
\hline & Kategori & & Kurang & & Sedang & & Baik & & Baik \\
\hline
\end{tabular}




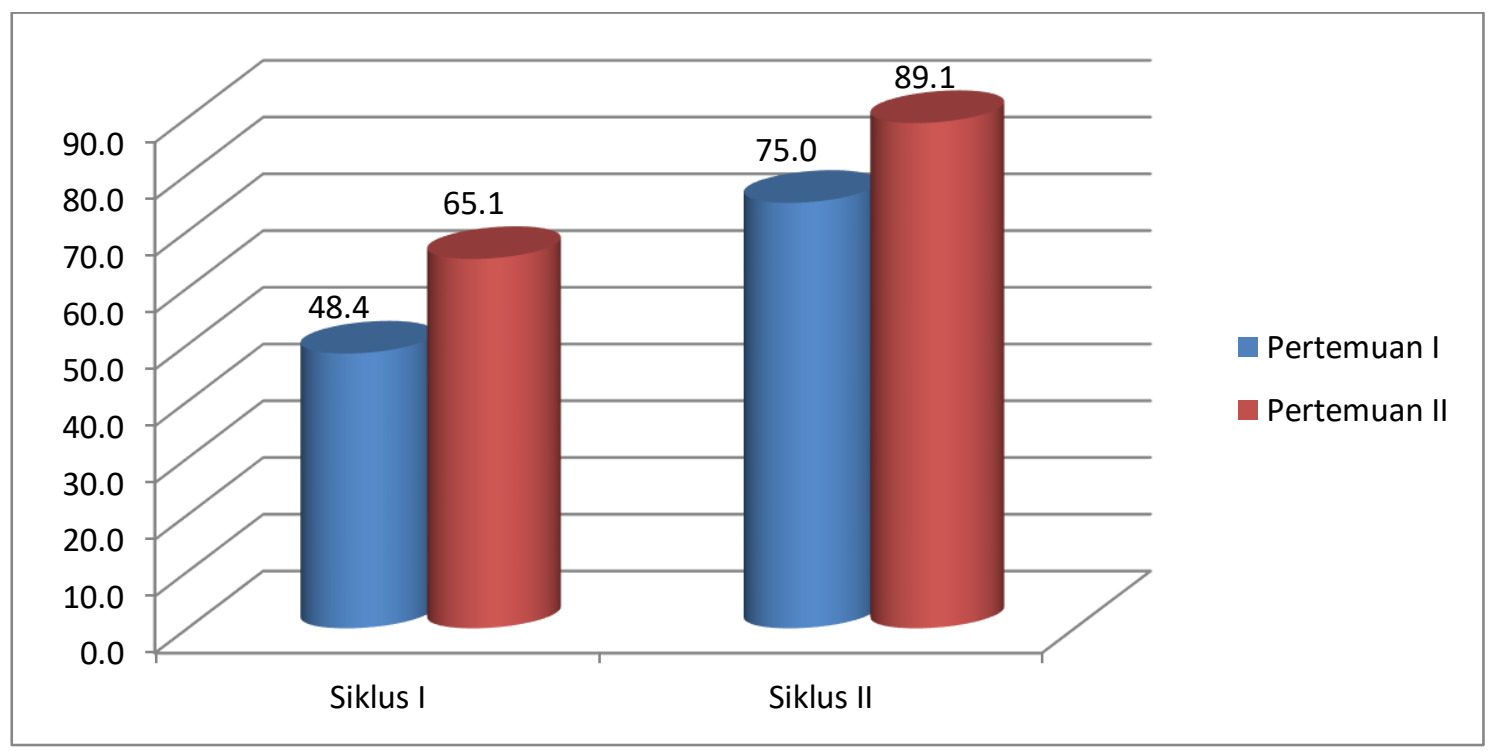

Gambar 2. Grafik Peningkatan Aktivitas Siswa

Berdasarkan grafik pada Gambar 1, sangat terlihat bahwa terjadi peningkatan aktivitas yang dilakukan guru dari tiap pertemuan dalam dua siklus. Yang mana pertemuan kedua dari siklus II merupakan aktivitas terbaik yang dilakukan guru dalam melaksanakan pembelajaran kooperatif tipe STAD.

\section{Aktivitas Siswa}

Pada siklus I aktivitas siswa dalam pembelajaran masih terlihat kurang baik karena siswa belum terbiasa dengan model pembelajaran yang dilakukan guru dan siswa juga kesulitan dalam mengerjakan LKS. Tetapi pada siklus II aktivitas siswa sudah banyak peningkatan, hal ini tarlihat pada aktivitas siswa dalam mengerjakan LKS, siswa semangat dalam mengerjakannya dan tidak malu untuk bertanya pada teman sekelompok dan guru. Hal ini terlihat aktivitas siswa sudah sesuai dengan yang direncanakan peneliti, sehingga hasil belajar siswa meningkat yang ditandai dengan hasil belajar siswa berupa ulangan harian tiap siklus dan pemahaman konsep.

Berdasarkan Gambar 2 dapat dilihat peningkatan aktvitas siswa mulai dari pertemuan pertama siklus I hingga pertemuan ketiga siklus II. Pada pertemuan pertama siklus I rata-rata skor adalah yang paling rendah, hal ini terjadi akibat siswa masih bingung dengan pembelajaran yang diterapkan guru yaitu pembelajaran kooperatif tipe STAD, sedangkan rata-rata skor tertinggi yaitu pada pertemuan ketiga siklus II hal ini karena siswa telah terbiasa dengan pembelajaran yang diterapkan guru.

\section{Analisis Hasil Belajar dan Ketercapaian KKM}

Berdasarkan Tabel 5, dapat disimpulkan bahwa ada peningkatan jumlah siswa dan persentase siswa yang mencapai KKM setelah penerapan pembelajaran kooperatif Tipe STAD. Peningkatan jumlah siswa sebanyak 7 orang siswa dan peningkatan ketercapaian KKM sebesar 21,86\% dari skor dasar ke siklus I. Selanjutnya, dari siklus I ke siklus II jumlah siswa meningkat sebanyak 7 orang siswa dan peningkatan ketercapaian KKM sebesar 21,86\%. Berdasarkan Tabel 5, rekapitulasi jumlah siswa dan persentase ketercapaian KKM dapat disimpulkan bahwa penerapan model pembelajaran kooperatif tipe STAD dapat meningkatkan hasil belajar siswa. 
Tabel 5. Rekapitulasi Jumlah Siswa dan Persentase Ketercapaian KKM

\begin{tabular}{lcc}
\hline \multirow{2}{*}{ Ulangan Harian } & \multicolumn{2}{c}{ Ketercapaian KKM } \\
\cline { 2 - 3 } & Jumlah Siswa Tuntas & $\%$ \\
\hline Sebelum Tindakan & 15 & 46.9 \\
Ulangan Harian I & 22 & 68.8 \\
Ulangan Harian II & 29 & 90.6 \\
\hline
\end{tabular}

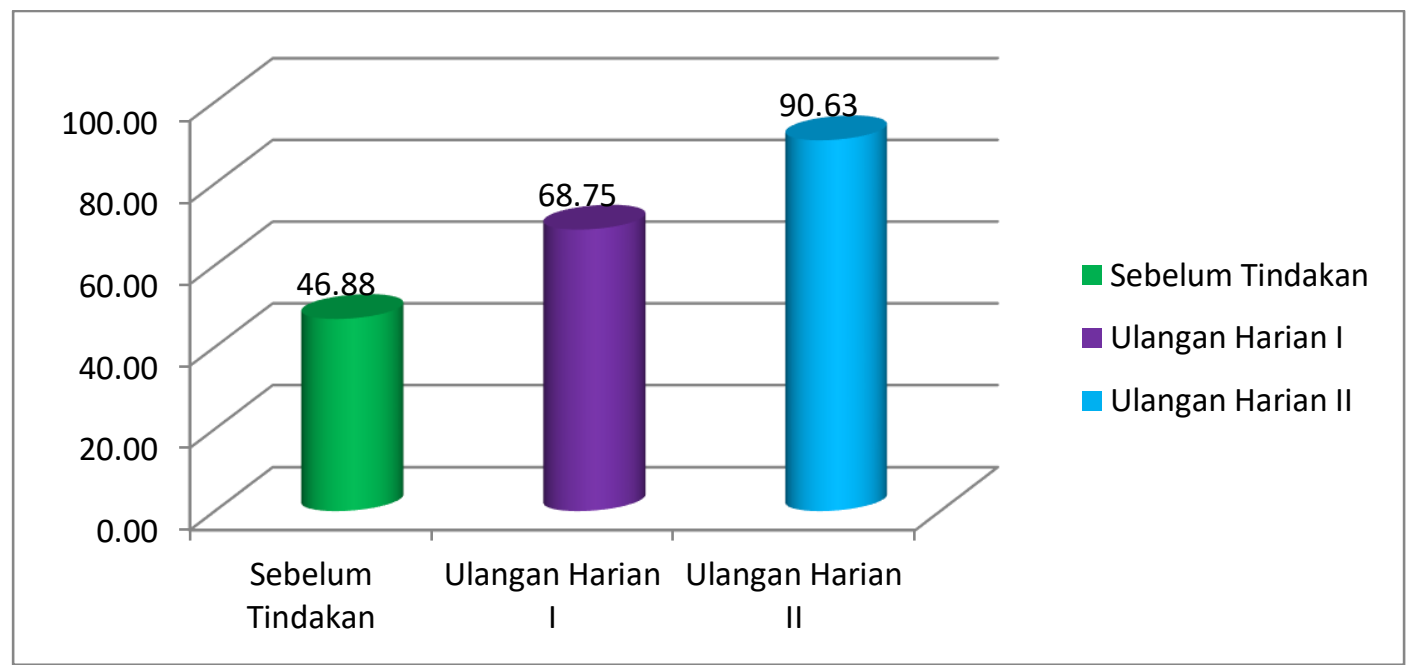

Gambar 3. Hasil Belajar Siswa

Hasil belajar yang diperoleh siswa pada sebelum tindakan, siklus I, dan siklus II dapat dilihat pada Gambar 3.

\section{Nilai Perkembangan dan Penghargaan Kelompok}

Nilai perkembangan dihitung pada setiap siklus.Nilai perkembangan siklus I dihitung berdasarkan selisih skor dasar dengan skor ulangan harian I, dan nilai perkembangan siklus II dihitung berdasarkan selisih skor ulangan harian I dengan skor ulangan harian II. Penyusunan kelompok pada pembelajaran kooperatif Tipe STAD siklus I berdasarkan nilai skor dasar, dan penyusunan kelompok siklus II sama dengan kelompok pada siklus I. Nilai perkembangan siswa pada siklus I dan siklus II dapat dilihat pada Tabel 6.
Berdasarkan Tabel 6, jumlah siswa yang memperoleh nilai perkembangan 30 pada siklus I berjumlah 9 siswa dan pada siklus II menjadi19 siswa.Nilai perkembangan 20 jumlah siswa pada siklus I berjumlah 20 siswa sedangkan pada siklus II meningkat menjadi 13 siswa.Nilai perkembangan 10 pada siklus I sebanyak 3 orang siswa mengalami penurunan pada siklus II menjadi tidak ada, Tidak ada siswa yang mendapatkan nilai perkembangan 5. Selanjutnya, pada siklus I terdapat 1 kelompok super, dengan nilai perkembangan 20-30, 1 kelompok hebat, dan 4 kelompok baik. Pada siklus II terdapat 6 kelompok super. Penghargaan kelompok pada siklus I dan siklus II dapat dilihat pada Gambar 4. 
Tabel 6. Nilai Perkembangan Siswa pada Siklus I dan Siklus II

\begin{tabular}{ccccc}
\hline \multirow{2}{*}{ Nilai Perkembangan } & \multicolumn{2}{c}{ Siklus I } & \multicolumn{2}{c}{ Siklus II } \\
\cline { 2 - 5 } & $\begin{array}{c}\text { Jumlah } \\
\text { Siswa }\end{array}$ & $\begin{array}{c}\text { Persentase } \\
(\%)\end{array}$ & $\begin{array}{c}\text { Jumlah } \\
\text { Siswa }\end{array}$ & Persentase (\%) \\
\hline 5 & 0 & 0 & 0 & 0 \\
\hline 10 & 3 & 9.4 & 0 & 0 \\
\hline 20 & 20 & 62.5 & 13 & 40.6 \\
\hline 30 & 9 & 28.1 & 19 & 59.4 \\
\hline
\end{tabular}

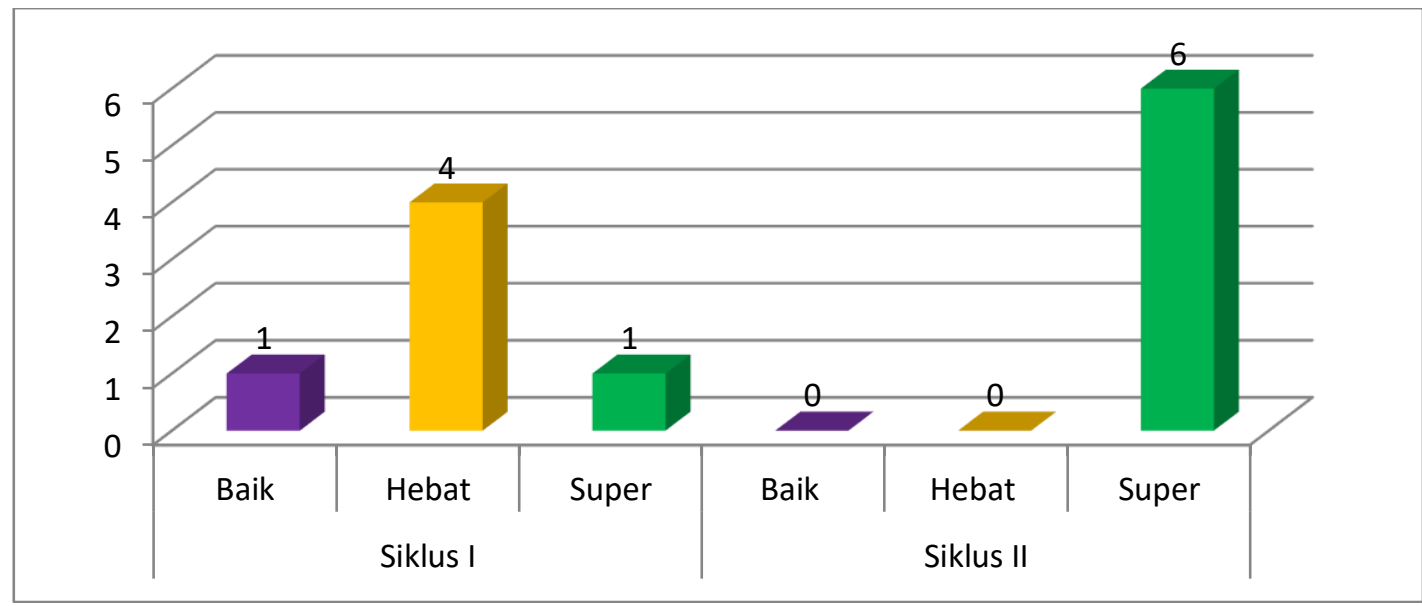

Gambar 4. Penghargaan Kelompok

\section{PENUTUP}

Berdasarkan pembahasan hasil penelitian dan refleksi, dapat disimpulkan sebagai berikut.

1. Aktivitas guru pada siklus I pertemuan I memperoleh $62.5 \%$ dengan kategori sedang, kemudian mengalami peningkatanpada pertemuan kedua siklus I menjadi $70.8 \%$ dengan kategori baik. Setelah dilaksanakan siklus II pertemuan I menjadi $87.5 \%$ dengan kategori baik dan pada pertemuan kedua siklus II menjadi $95.8 \%$ dengan kategori sangat baik.

2. Aktivitas siswa juga mengalami peningkatan dari $48.4 \%$ dengan kategori kurang pada pertemuan pertama siklus I meningkat menjadi $65.1 \%$ dengan kategori sedang pada pertemuan kedua siklus I. Kemudian pada siklus II pertemuan pertama aktivitas siswa meningkat menjadi
75\% dengan kategori baik. Setelah dilaksanakan pertemuan kedua siklus II kembali meningkat menjadi $89.1 \%$ dengan kategori baik.

3. Ketuntasan belajar siswa meningkat pada siklus I dari 32 orang siswa, yang mencapai ketuntasan berjumlah 22 orang siswa dengan persentse $68.8 \%$ dan siswa yang tidak tuntas 10 orang dengan persentase $31.2 \%$. Sedangkan pada siklus II siswa yang dikatakan tuntas 29 orang atau $90.6 \%$ dari 32 orang siswa dan siswa yang tidak tuntas 3 orang atau $9.4 \%$

4. Peningkatan hasil belajar siswa disebabkan oleh penerapan model pembelajaran kooperatif tipe STAD. Ini dapat dilihat dari meningkatnya aktivitas siswa dalam proses pembelajaran dengan menerapkan model pembelajaran kooperatif tipe STAD. 


\section{UCAPAN TERIMA KASIH}

Terbitnya tulisan ini tidak terlepas dari bantuan berbagai pihak, untuk itu penulis ucapkan terima kasih kepada UP3M STKIP PGRI Sumatera Barat dan pengelola jurnal Pelangi yang telah memberikan saran dan revisi dalam penulisan artikel ini.

\section{DAFTAR PUSTAKA}

Ali, M., et al. (2007). Ilmu Dan Aplikasi Pendidikan. Bandung: Tim Pengembangan Ilmu Pendidikan FIP-UPI.

Arikunto,S.et.al. (2010). Penelitian Tindakan Kelas. Jakarta: PT Bumi Aksara.

Depdiknas. (2006). Kurikulum Tingkat Satuan pendidikan. Jakarta: Pusat Kurikulum. Balitbang Depdiknas.

Dimyati dan Mudjiono. ( 2008). Belajar dan Pembelajaran. Jakarta: Rineka Cipta

Ibrahim, Muslimin, dkk. (2000). Pembelajaran Kooperatif. Surabaya: Universitas Negeri Surabaya

Kunandar. (2011). Guru Profesional Implementasi Kurikulum Tingkat Satuan Pendidikan (KTSP) Dan Persiapan Menghadapi Sertifikasi Guru.Jakarta: Raja Wali Press

Mulyasa, E. (2009). Praktik Penelitian Tindakan Kelas. Bandung: Remaja Rosda Karya.
Mulyasa, E. (2005). Menjadi Guru Profesional. Bandung: Remaja Rosda Karya.

Sadiman, A.S. et al. (2008). Media Pendidikan.Raja Grafindo Persada: Jakarta

Sanjaya, Wina. (2006). Pembelajaran Dalam Implementasi Kurikulum Berbasis Kompetensi. Jakarta: Prenada Media Group

Silberman.(2007). Active Learning. Yogyakarta: Yappendis.

Slavin, Robert E. (2008). Psikologi Pendidikan Teori dan Praktek 1. Jakarta: Indeks.

Sobel, M.A dan Maletsky E. M. (2004). Mengajar Matematika; Sebuah Buku Sumber Alat Peraga, Aktivitas dan Strategi.Jakarta: Erlangga

Solihatin, Etin dkk. (2007). Cooperative Learning, Analisis Model Pembelajaran IPS.Jakarta: Bumi Aksara.

Sudijono, Anas. (1995). Pengantar Evaluasi Pendidikan. Jakarta:PT Rajagrafindo Persada.

Syah, M. (2008). Psikologi Pendidkan Dengan Pendekatan Baru. Bandung: Remaja

Trianto. (2009). Mendesai Model Pembelajaran Inovatif -Progresif. Jakarta: Kencana Prenada Media Group. 